\title{
TURUT MEMBINA INDONESIA SEBAGAI RUMAH BERSAMA - PERAN GEREJA DALAM POLITIK DI INDONESIA
}

\author{
Zakaria J. Ngelow \\ Yayasan Oase Intim \\ zngelow@gmail.com
}

\begin{abstract}
Abstrak
Artikel ini ditulis dalam rangka orasi ilmiah pada perayaan Dies Natalis ke82 Sekolah Tinggi Theologia Jaffray di Makassar, dari suatu perspektif teologi tentang peran gereja dalam politik di Indonesia. Artikel ini terdiri atas dua bagian, yang pertama adalah tinjauan historis mengenai gereja dan politik di Barat, dari masa Perjanjian Baru sampai pasca-Reformasi ketika gereja berpisah dari negara. Bagian kedua, tentang gereja dan politik di Indonesia. Bagian inilah menjadi pokok uraian pada perayaan Dies Natalis ke-82. Pada bagian kedua ini, topiknya dibagi dalam beberapa bagian, yaitu latar belakang historitas agama dan politik di Indonesia modern, partisipasi Kristen dalam politik di Indonesia, demokrasi prosedural-transaksional dalam konteks politik saat ini dan diakhiri dengan beberapa poin bagaimana gereja berperan dalam mengembangkan substansi demokrasi di Indonesia. Bingkai teologi peran gereja dalam politik adalah misi gereja untuk menghadirkan tanda-tanda Kerajaan Allah di bumi, di antaranya kebenaran, kedamaian dan kemakmuran bagi semua ciptaan. Politik Kristen bukanlah politik kekuasaan atau untuk kepentingan diri sendiri, tetapi politik untuk melayani dan memperjuangkan kepentingan umum demi kebaikan semua orang dan seluruh ciptaan.
\end{abstract}

Kata-kata kunci :gereja, ciptaan, politik, demokrasi, agama

This article was written as a theological oration to celebrate the $82^{\text {nd }}$ anniversary of Jaffray Theological Seminary in Makassar. It is a theological perspective on the role of the church in Indonesian politics. This article consist of two parts, the first is a historical overview of church and politics in the West, from the New Testament period to the post-reformation period when the church was separated from the state. The second part is on the church and politics in Indonesia. This is the part that was delivered as the theological speech at the $82^{\text {nd }}$ celebration. In this second part various aspects of the topic were elaborated: the historical background of religion and politics in modern Indonesia; Christian's participation in Indonesian politics; the context of the recent political situation of proceduraltransactional democracy; and finally some points about the church's role in developing substantial democracy for Indonesia. The theological framework 
for the political role of the church is that the mission of the church is to implement the signs of the Kingdom of God, i.e. justice, peace, and welfare for all of creation. Christian politics is not the politics of power or of selfinterest, but the politics of service and struggle for the common good of people and creation.

Keywords : church, creation, politics, democracy, religion

\section{Dari Yerusalem ke Roma}

Studi mengenai hidup Yesus menunjukkan bahwa Dia bukanlah anggota gerakan perjuangan kemerdekaan Yahudi terhadap penjajah Romawi. Tetapi Injil Kerajaan Allah yang nyata dalam pelayanan dan ajaran-Nya merupakan suatu perubahan radikal terhadap tatanan sosial dan politik. Ucapan dan tindakan Yesus mengedepankan suatu tantangan konsisten terhadap semua sikap, praktik dan struktur yang cenderung sewenang-wenang membatasi atau menyingkirkan warga persekutuan masyarakat. Yesus mencari mereka yang disisihkan, mereka yang dipinggirkan dari persekutuan, dan memberi tempat dalam oikos, rumah, kediaman di mana semua orang hidup bersama dalam kasih dan pelayanan.

Walaupun tidak bersalah, Yesus disalibkan oleh Pontius Pilatus karena tekanan para ulama Yahudi. ${ }^{1}$ Yesus mati dan dikuburkan, namun pada hari ketiga dibangkitkan dari kematian, ${ }^{2}$ dan kebangkitan-Nya itu adalah bukti tindakan penebusan Allah yang terkait dengan masa depan baru umat manusia. Para rasul, yakni murid-murid Yesus, memberitakan kabar baik ini, dan oleh kuasa Roh Kudus orang-orang dari berbagai latar belakang sosial, ras, budaya, terhimpun menjadi suatu persekutuan baru, yang disebut ekklesia, orang-orang yang dipanggil dari kegelapan ke dalam terang kebenaran Injil (band. 1 Petrus 2:9). Persekutuan baru ini mula-mula terhubung dengan agama Yahudi, namun kemudian bersilang jalan, terutama dalam hal iman kepada Yesus sebagai Sang Mesias yang dijanjikan, dan dalam penekanan pada hakekat gereja sebagai persekutuan iman yang melampaui ke-Yahudi-an, yang menghimpun kebersamaan semua orang dalam kasih persaudaraan dan kesetaraan umat manusia:

\footnotetext{
${ }^{1}$ Penyaliban adalah hukuman keji khas Romawi, khususnya untuk pemberontak dan budak yang melarikan diri. Lihat "Crucifixion", diakses 4 Agustus, http://en.wikipedia.org/wiki/Crucifixion.

${ }^{2}$ Perhatikan bahwa Alkitab menyebut "Yesus dibangkitkan" bukan bangkit sendiri. Rasul Paulus merangkum makna kebangkitan Yesus dalam Roma 6:4-5.
} 
Dalam hal ini tidak ada orang Yahudi atau orang Yunani, tidak ada hamba atau orang merdeka, tidak ada laki-laki atau perempuan, karena kamu semua adalah satu di dalam Kristus Yesus (Galatia 3:28).

Secara geografis para rasul dan penerus mereka memberitakan Injil "di Yerusalem dan di seluruh Yudea dan Samaria dan sampai ke ujung bumi" (Kisah Para Rasul 1:8). Seorang Uskup dari Gereja Ortodoks di India mengatakan bahwa gerejanya yang dibangun oleh Rasul Tomas telah berdiri sejak tahun 52 Masehi, hanya 23 tahun setelah peristiwa Pentakosta. ${ }^{3}$ Alkitab Perjanjian Baru meriwayatkan perjalanan-perjalanan penginjilan Rasul Paulus dari Yerusalem ke Asia Kecil sampai benua Eropa.

Perlu catatan khusus terhadap dua peran Rasul Paulus. ${ }^{4}$ Pertama, kerajinan dan prestasinya memberitakan Injil dan membentuk jemaatjemaat sangat menonjol dari rasul-rasul lainnya, sebagaimana diungkapkan dalam Kisah Para Rasul. ${ }^{5}$ Yang kedua, kedalaman teologinya. Dari semua rasul, Rasul Paulus yang terpelajar, menguasai teologi Yahudi sebagai seorang Farisi (Filipi 3:5) dan sempat belajar dari Gamaliel, rabi Yahudi terkemuka (Kisah Para Rasul 22:3) di Yerusalem, cucu Rabi Hillel yang ternama. ${ }^{6}$ Paulus juga memahami pemikiran filsafat Hellenis, seperti Stoisisme dan Neo-Platonisme, yang memungkinkannya menjelaskan Injil Kristus dalam wacana intelektual dunia pada masa itu. Keterpelajarannya dibuktikan dengan tulisantulisan yang kini menjadi bagian dari Alkitab Perjanjian Baru. ${ }^{7}$ Rasul

\footnotetext{
${ }^{3}$ Lihat informasi Wikipedia, "Thomas the Apostle", diakses 4 Agustus 2014, http://en.wikipedia.org/wiki/Thomas_the_Apostle.

${ }^{4}$ Dalam Perjanjian Baru, jabatan rasul hanya untuk para murid Yesus sebagai saksi langsung kehidupan, sengsara dan kebangkitan Yesus Kristus (band. Kisah Para Rasul l: 21-22). Paulus mengklaim kerasulannya berdasar pada wahyu langsung: "Sebab aku menegaskan kepadamu, saudara-saudaraku, bahwa Injil yang kuberitakan itu bukanlah injil manusia. Karena aku bukan menerimanya dari manusia, dan bukan manusia yang mengajarkannya kepadaku, tetapi aku menerimanya oleh penyataan Yesus Kristus" (Galatia 1:11-12). Untuk rangkuman informasi mengenai Rasul Paulus, lihat "Paul the Apostle", diakses 4 Agustus 2014 http://en.wikipedia.org/wiki/Paul_the_Apostle.

${ }^{5}$ Dalam Alkitab terjemahan baru terbitan LAI disertakan peta perjalananperjalanan Rasul Paulus memberitakan Injil di Asia dan Eropa, dan perjalanan ke Roma sebagai pesakitan. Lihat peta "The Missionary Journeys of the Apostle Paul", diakses 14 Agustus, https://www.lds.org/scriptures/bc/images/03990_000_biblemap-13.pdf.

${ }^{6}$ Mengenai Rabi Gamaliel, lihat "Gamaliel”, diakses 4 Agustus 2014, http://en.wikipedia.org/wiki/Gamaliel; dan kakeknya, Rabi Hillel (Hillel the Elder) diakses 4 Agustus 2014, http://en.wikipedia.org/wiki/Hillel_the_Elder.

${ }^{7}$ Secara tradisional Rasul Paulus diakui sebagai penulis 13 kitab Perjanjian Baru. Demikian besar peran Rasul Paulus dan mengembangkan Kekristenan
} 
Paulus adalah teladan bagi civitas akademik pendidikan teologi, dalam hal perpaduan antara komitmen penyerahan diri dan mutu keterpelajaran. [Ditengarai di Indonesia dewasa ini banyak sekolahsekolah teologi dengan program studi yang hanya mengejar formalitas, tetapi makin dangkal substansi (ber)teologinya].

Selama hampir 300 tahun persekutuan umat Kristen itu berkembang di tengah-tengah berbagai penghambatan. Permusuhan dan penghambatan pemerintah dan masyarakat kepada mereka, terutama karena orang Kristen tidak bersedia mengakui keilahian kaisar Romawi yang memaksa mereka mengungsi dari satu tempat ke tempat lain; tetapi bersama dengan itu berita Injil menyebar ke berbagai daerah dalam lingkup kekaisaran Romawi (oikoumene), bahkan sampai melintasi batas-batasnya. Mereka setia dalam iman, mengalami berbagai siksaan sampai mati, dan mewariskan sejarah para martir Kristen, laki-laki dan perempuan, yang bermakna bagi perkembangan gereja. Darah para martir adalah benih pertumbuhan gereja, demikian dinyatakan Tertullianus (162-225 M), Bapa Gereja dari Kartago, Afrika Utara. ${ }^{8}$ Memang gereja purba tidak meninggalkan gedung-gedung megah melainkan katakombe, loronglorong kuburan dan persembunyian bawah tanah di Roma, Napoli (Naples), Sirakusa (Syracuse), Malta, Kapadokia (Cappadocia) dan Tunisia. Katakombe di Roma kini menjadi objek wisata rohani. ${ }^{9}$ Gereja purba juga meninggalkan pemikiran teologi yang dikenal sebagai kepustakaan Bapa-bapa Gereja (Patristic literature). ${ }^{10}$ Sejarah Kekristenan mula-mula selama tiga abad itu berhasil memperlengkapi gereja dengan apa yang disebut senjata-senjata gereja, yakni kanon

\footnotetext{
sehingga ada sarjana-sarjana yang menyatakan agama Kristen dibentuk oleh Rasul Paulus. Lihat beberapa informasi dalam Carl Olson, "Did St. Paul Invent Christianity?", diakses 4 Agustus 2014,

http://www.catholic.com/magazine/articles/did-st-paul-invent-christianity.

${ }^{8}$ Untuk pengantar mengenai martir Kristen, bacalah "Christian martyrs", diakses 4 Agustus 2014, http://en.wikipedia.org/wiki/Christian_martyrs. Mengenai Tertullianus, 4 Agustus 2014, http://en.wikipedia.org/wiki/Tertullian.

${ }^{9}$ Lihat "Early Christian Catacombs", tersedia di http://www.sacreddestinations.com/italy/rome-catacombs. Beberapa ilustrasi menarik "Christian Catacombs", diakses 4 Agustus 2014, http://www.biblearchaeology.info/catacombs.htm.

${ }^{10}$ Online link ke edisi bahasa Inggris al. terdapat dalam "Online Patristic Texts" diakses 4 Agustus 2014, http://guides.lib.cua.edu/content.php?pid=160231\& $\approx$ sid=1635422
} 
Alkitab, Pengakuan Iman Rasuli, dan suksesi para pejabat gereja, yang berfungsi mempersatukan gereja dalam kepelbagaiannya, dan melindunginya dari berbagai ajaran yang menyimpang.

\section{Dua Kuasa}

Kesetiaan iman dan persaudaraan kasih umat Kristen memperkuat posisi sosialnya sehingga penguasa Romawi tidak bisa menolak keberadaan agama Kristen. Kaisar Konstantinus Agung menerbitkan Edik Milano tahun 313 yang mengakui agama Kristen. Penetapan agama Kristen sebagai agama resmi kekaisaran Romawi oleh Kaisar Teodosius Agung (380 M) mengubah hubungan gereja dengan kekuasaan, dari yang ditolak-ditindas-diabaikan menjadi yang disambut dan diberi posisi penting." Bahkan kemudian gereja memenangkan pertarungan antara Kaisar versus Paus memperebutkan kuasa tertinggi. Sri Paus Gelasius I (492-496 M) mengembangkan ajaran dua pedang, yang intinya mengenai adanya dua kekuasaan yaitu kekuasaan rohani gereja dan kekuasaan duniawi kaisar, di mana kekuasaan duniawi tunduk pada yang rohani. ${ }^{12}$ Ajaran supremasi kuasa gereja ini, yang merupakan bentuk tertentu theocracy, berlaku dalam hubungan gereja dan negara di Eropa selama lebih dari seribu tahun, yakni sampai terjadi pemisahan gereja dan negara. Sebaliknya, ada usaha-usaha menempatkan kekuasaan gereja di bawah kekuasaan politik negara, yang disebut caesaropapism, sebagaimana sempat dijalankan oleh para kaisar Byzantium (Romawi Timur) atas Gereja Timur pada abad ke-4 sampai ke-10, dan oleh kekaisaran Rusia atas Gereja Ortodoks Rusia pada abad ke-16 sampai abad ke-18. ${ }^{13}$

\footnotetext{
11 "State church of the Roman Empire", diakses 4 Agustus 2014, http://en.wikipedia.org/wiki/State_church_of_the_Roman_Empire.

12 "There are two powers, august Emperor, by which this world is chiefly ruled, namely, the sacred authority of the priests and the royal power. Of these that of the priests is the more weighty, since they have to render an account for even the kings of men in the divine judgment. You are also aware, dear son, that while you are permitted honorably to rule over human kind, yet in things divine you bow your head humbly before the leaders of the clergy and await from their hands the means of your salvation... And if it is fitting that the hearts of the faithful should submit to all priests in general who properly administer divine affairs, how much the more is obedience due to the bishop of that see [Rome] which the Most High ordained to be above all others, and which is consequently dutifully honored by the devotion of the whole Church." The New World Encyclopedia s.v. "Gelasius I", diakses 10 Agustus 2014 http://www.newworldencyclopedia.org/entry/Gelasius_I.

13“"Caesaropapism”, diakses 4 Agustus 2014, http://en.wikipedia.org/wiki/Caesaropapism.
} 
Reformator Protestan abad ke-16 di Eropa, Martin Luther (1483$1546 \mathrm{M}$ ), menerima kontrol pemerintah atas pemerintahan gereja, mengikuti prinsip cuius regio, eius religio (Latin: siapa memerintah, agamanya dianut) ${ }^{14}$ sementara Yohannes Calvin (1509-1564 M) di Jenewa, lebih mandiri, bahkan sempat menjalankan semacam teokrasi di mana gereja malah memperoleh dukungan pemerintah kota dalam pelaksanaan disiplin dan pelayanan gereja. Di Inggris, Raja Henry VIII melakukan perlawanan kepada Sri Paus di Roma dan melepaskan dan membarui Gereja Inggris ${ }^{15}$ dari Gereja Katolik sehingga berkembang menjadi tradisi gerejawi tersendiri. ${ }^{16}$

Pemisahan gereja dan negara terjadi dalam sejarah gereja di Eropa, karena pengaruh gerakan kebudayaan Renaissance dan Pencerahan (Jerman: Aufklärung). Pada bagian akhir Abad-abad Pertengahan di Eropa berlangsung beberapa perkembangan penting, yang dimulai dengan Renaissance (kebangunan kembali), yakni kelahiran kembali kebudayaan klasik Latin dan Yunani di Italia pada abad ke-14 sampai abad ke-17. ${ }^{17}$ Gerakan kebudayaan yang menekankan kemanusiaan ini, ${ }^{18}$ menyediakan terjemahan bahanbahan pengetahuan klasik, yang dimanfaatkan oleh para tokoh Pencerahan mengembangkan ilmu pengetahuan modern. Para tokoh Pencerahan mengedepankan penggunaan akal budi dan logika untuk memahami dunia, bukannya menerima kebenaran yang dibakukan

\footnotetext{
${ }^{14}$ Semboyan ini ditetapkan pada Pertemuan Augsburg tahun 1555 terkait kenyataan reformasi gereja di Eropa: ada negara-negara yang diperintah raja Katolik, ada yang Protestan. Informasi diakses 10 Agustus 2014, http://en.wikipedia.org/wiki/Cuius_regio,_eius_religio.

${ }^{15}$ Baca pengantar "English Reformation", diakses 4 Agustus 2014,http://en.wikipedia.org/wiki/English_Reformation. Sampai sekarang Raja Inggris menjadi Kepala (Supreme Gouvernor) Gereja Inggris.

${ }^{16}$ Dikenal sebagai Gereja Anglikan. Lihat “Anglicanism”, diakses 4 Agustus 2014, http://en.wikipedia.org/wiki/Anglicanism.

${ }^{17}$ Baca pengantar "The Renaissance" tersedia di http://en.wikipedia.org/wiki/The_Renaissance. Untuk tokoh-tokoh kesenian Renaissance, baca "HISTORY OF THE RENAISSANCE “,diakses 10 Agustus 2014, http://www.historyworld.net/wrldhis/plaintexthistories.asp?historyid=ac88.

${ }^{18}$ Berbeda dengan humanisme modern (berkembang sejak abad ke-19), inti humanisme renesans adalah kemampuan berbahasa lisan (orator) maupun bahasa tulis (menggubah puisi dan/atau prosa), dengan mempelajari dengan saksama dan meniru para tokoh besar sastrawan klasik. Dengan menguasai bahasa secara gramatik orang dapat maju pada tahap selanjutnya, yakni keindahan berbahasa atau retorika. Seni retorika adalah kemampuan mempengaruhi orang, pria dan wanita, untuk menjalani hidup yang lebih berkualitas, hidup sebagai manusia (Italy: umanista). Dalam perkembangannya studi bahasa para humanis renesans meliputi tata bahasa, retorika, puisi, etika (filsafat moral) dan sejarah. Baca "Humanism" diakses 4 Agustus 2014, http://en.wikipedia.org/wiki/Humanism.
} 
tradisi atau yang dijadikan doktrin agama (=gereja). ${ }^{19}$ Immanuel Kant (1724-1804 M) memperkenalkan semboyan "Sapere aude" (beranilah berpikir), ${ }^{20}$ dan René Descartes (1596-1650 M) menyatakan "Cogito ergo sum" (Aku berpikir maka aku ada). ${ }^{21}$ Kedua semboyan ini sama menegaskan kemampuan manusia dan mendorong manusia menggunakan akalnya untuk menemukan dan/atau memahami kebenaran kehidupan.

Demikianlah maka tradisi yang lazim diterima bahwa penyelenggaraan pemerintahan dilaksanakan dalam suatu sistem yang mengikat kuasa duniawi dengan kuasa rohani mulai dipertanyakan. Pemisahan gereja dan negara bertolak dari pemikiran bahwa dalam urusan agama, yaitu relasi pribadi seseorang dengan Yang Ilahi, negara atau pemerintah tidak punya kewenangan; pemerintah tidak boleh mencampuri keputusan hati nurani seseorang. Urusan agama bukan urusan negara, atau masyarakat, melainkan urusan pribadi yang menjadi tanggung jawab lembaga agama yang bersangkutan. ${ }^{22}$ Sejajar dengan itu Martin Luther mengemukakan ajaran dua kerajaan dengan menekankan bahwa kuasa duniawi tidak punya kewenangan untuk campur tangan dalam urusan kerajaan rohani. Dengan kata lain, pemerintah tidak berkuasa apa-apa dalam urusan ajaran, ibadah dan pemerintahan gerejawi.

Orang beriman taat kepada kuasa pemerintahan dan pengaturannya sejauh tidak mengikat hati nurani melainkan hanya urusan lahiriah. Namun jika kuasa pemerintah memasuki wilayah rohani dan memaksa hati nurani, yang hanya boleh dituntun dan diatur Allah, kita harus tegas menolak, bahkan sekali pun kita harus kehilangan nyawa. Kuasa dan pemerintahan duniawi terbatas hanya pada masalah-masalah eksternal dan jasmaniah. ${ }^{23}$

\footnotetext{
${ }^{19}$ Mengenai "Pencerahan", diakses 4 Agustus 2014, http://plato.stanford.edu/entries/enlightenment/.

20 "Sapere aude", diakses 10 Agustus 2014, http://en.wikipedia.org/wiki/Sapere_aude.

21 "Cogito ergo sum" diakses 10 Agustus 2014, http://en.wikipedia.org/wiki/Cogito_ergo_sum.

${ }^{22}$ John Locke (1632-1704), filsuf Pencerahan dari Inggris, dianggap tokoh utama yang menggagas pemisahan gereja dan negara. Lihat "Separation of church and state" diakses 10 Agustus 2014, http://en.wikipedia.org/wiki/Separation_of_church_and_statełEnlightenment.

${ }^{23}$ "We are to be subject to governmental power and do what it bids, as long as it does not bind our conscience but legislates only concerning outward matters... But if it invades the spiritual domain and constrains the conscience, over which God
} 
Pemahaman itu terkait pula dengan perkembangan sikap toleransi beragama, yang muncul akibat perbedaan-perbedaan denominasi Kristen karena Reformasi gereja. ${ }^{24}$ Menyambut Reformasi, masing-masing negara menerapkan agama pilihan rajanya, Katolik, Reformed atau Lutheran. Namun dinamika sosial politik dan kemunculan banyak denominasi Protestan akhirnya memaksa pemerintah masing-masing negara Eropa mulai bertoleran pada perbedaan dan menjamin kebebasan beragama semua warganya. ${ }^{25}$ Pada perkembangan selanjutnya negara-negara modern makin meninggalkan opsi negara agama, dan membiarkan urusan agama menjadi urusan pribadi warganya. Memang di sejumlah negara ada partai-partai politik berdasar agama (Kristen) yang tidak lagi bercitacita teokratis, hanya sebagai pilihan masuk ke dalam lingkaran kekuasaan.

\section{Ketuhanan Yang Maha Esa}

Sila pertama Pancasila, mula-mula dirumuskan sebagai sila ke-5, "Ketuhanan" dengan tambahan tujuh kata "dengan kewajiban menjalankan syariah Islam bagi pemeluk-pemeluknya". Hasil kompromi antara kelompok ideologi kebangsaan dengan kelompok ideologi Islam ini, ditolak oleh wakil-wakil Kristen dan Katolik dari

only must preside and rule, we should not obey it at all but rather lose our necks. Temporal authority and government extend no further than to matters which are external and corporeal." Lihat "Two kingdoms doctrine", diakses 10 Agustus 2014, http://en.wikipedia.org/wiki/Doctrine_of_the_two_kingdoms.

${ }^{24}$ Toleransi maknanya menerima apa yang tidak disetujui, yang kemudian bermakna persetujuan atau dukungan pihak yang lebih kuat terhadap keberadaan yang lebih lemah, yang diterjemahkan dalam hubungan antar-agama. Wikipedia mencatat: "Toleration is 'the practice of deliberately allowing or permitting a thing of which one disapproves. One can meaningfully speak of tolerating-i.e., of allowing or permitting — only if one is in a position to disallow.' It has also been defined as 'to bear or endure' or 'to nourish, sustain or preserve.' Toleration may signify 'no more than forbearance and the permission given by the adherents of a dominant religion for other religions to exist, even though the latter are looked on with disapproval as inferior, mistaken, or harmful,"' diakses 10 Agustus 2014, http://en.wikipedia.org/wiki/Toleration.

${ }^{25}$ Ada perbedaan pendapat mengenai aspek-aspek kebebasan beragama, yang meliputi kebebasan memilih, menjalankan (beribadah dan sebagainya),

menyebarkan (dan mengajarkan) keyakinan agama. Perbedaan mengenai kebebasan memilih seharusnya juga bermakna kebebasan berpindah agama; bahkan ada yang juga menghubungkan dengan kebebasan memilih untuk tidak beragama. Lihat "Freedom of religion" diakses 10 Agustus 2014, http://en.wikipedia.org/wiki/Freedom_of_religion. 
Indonesia bagian Timur. Maka pada tanggal 18 Agustus 1945 disepakati perumusan baru, yakni "Ketuhanan Yang Maha Esa".

Bagaimanakah memahami sila "Ketuhanan Yang Maha Esa"? Pertama-tama sila pertama ini adalah rumusan politik, bukan rumusan pengakuan iman atau definisi teologi. Karena itu pemaknaan sila "Ketuhanan Yang Maha Esa" sebaiknya diletakkan dalam konteks perumusan dan tujuannya, yakni kompromi antara ideologi Islam dan ideologi kebangsaan. Hasilnya adalah suatu jalan tengah, bahwa Indonesia bukan negara agama, bukan pula negara sekuler, melainkan negara demokrasi modern yang mengakui adanya keilahian, dan karena itu menghormati agama-agama dan keber-agama-an warganya. Pada jalan tengah ini terdapat jaminan kebebasan beragama (dan pelayanan urusan agama) bagi warga negara. ${ }^{26}$ Dalam pelaksanaannya pemerintah membentuk Departemen Agama (kini Kementerian Agama), mula-mula untuk kepentingan khusus umat Islam, namun kemudian juga untuk semua umat beragama. ${ }^{27}$ Kuasa pengaturan negara hanya sampai pada aspek kelembagaan sosial agama, bukan pada doktrin, ritual, pejabat atau susunan organisasi keagamaannya. Negara (misalnya pengadilan) tidak bisa mencampuri dan menentukan benar atau tidak benarnya ajaran suatu aliran agama atau kepercayaan seseorang. ${ }^{28}$ Salah satu pokok perdebatan terkait adalah apakah negara/pemerintah berwenang mengakui atau tidak mengakui suatu agama.

Dalam perjalanan bangsa kita, muncul masalah-masalah antaragama, khususnya pembatasan pekabaran Injil (penyiaran agama) dan pembangunan gedung gereja (rumah ibadat), yang sampai sekarang

${ }^{26}$ UUD 1945 Pasal 29: (1) Negara berdasar atas Ketuhanan Yang Maha Esa. (2) Negara menjamin kemerdekaan tiap-tiap penduduk untuk memeluk agamanya masing-masing dan untuk beribadat menurut agamanya dan kepercayaannya itu.

27 "Sejarah Pembentukan Kementerian Agama", diakses 4 Agustus 2014, http://e-dokumen.kemenag.go.id/files/r5yH4vPql326688439.pdf.

${ }^{28}$ Ada kritik terhadap salah satu pasangan capres/cawapres yang lalu terkait dengan manifesto partainya, yang memberi kepada negara "menjamin kemurnian agama", yang bermakna campur tangan pemerintah dalam urusan ajaran/ibadah agama: "Setiap orang berhak atas kebebasan beragama dan menjalankan ibadah sesuai dengan agama dan kepercayaannya. Negara menjamin kemerdekaan tiap-tiap penduduk untuk memeluk agama/kepercayaan. Namun, pemerintah/negara wajib mengatur kebebasan di dalam menjalankan agama atau kepercayaan. Negara juga dituntut untuk menjamin kemurnian ajaran agama yang diakui oleh negara dari segala bentuk penistaan dan penyelewengan dari ajaran agama." Lihat "Manifesto Perjuangan Partai Gerakan Indonesia Raya", diakses 10 Agustus 2014, http://partaigerindra.or.id/uploads/Manifesto-Perjuangan-Partai-Gerindra.pdf. 
masih terus jadi masalah. ${ }^{29}$ Aturan-aturan diskriminatif dari zaman Orde Baru bukannya dicabut, malahan ada pihak yang berusaha menjadikannya dasar hukum yang lebih kuat lagi (UU Kerukunan Umat Beragama). ${ }^{30}$ Bahkan FKUB, wadah bentukan pemerintah bagi para pemuka agama untuk urusan kerukunan, dilaporkan di berbagai tempat lebih berfungsi sebagai legitimasi terhadap diskriminasi mempersulit rekomendasi pembangunan atau renovasi gedung gereja. Sementara itu desentralisasi dengan otonomi daerah telah membuka kesempatan bagi kalangan Islam politik untuk mengembangkan peraturan daerah bernuansa syariah Islam, yang merisaukan karena bersifat diskriminatif dalam masyarakat majemuk, dan merupakan politisasi agama, yang tidak sehat bagi perkembangan demokrasi. ${ }^{31}$

Masalah lain adalah adanya gerakan-gerakan intoleran "pemurnian agama", yang berusaha membersihkan agama dari berbagai unsur yang dianggap asing atau sesat, dengan cara-cara kekerasan, dan bersikap intoleran terhadap pemeluk agama-agama yang berbeda dengan paham yang dianut kelompok mayoritas. Para penganut Ahmadiah, Syi'ah, Baha'i dan juga penganut agama-agama lokal mengalami penindasan. Keadaan ini menimbulkan keprihatinan berganda: prihatin pada tindakan intoleran kelompok orang yang melanggar HAM kebebasan beragama itu; dan lebih prihatin lagi atas pembiaran pemerintah terhadap intoleransi itu dan tidak berusaha melindungi hak-hak warga negara sebagaimana mestinya. Pemerintah juga sering membiarkan saja sepak terjang kekerasan kelompokkelompok intoleran, baik lokal maupun yang terkait dengan gerakangerakan radikal transnasional. ${ }^{32}$

\footnotetext{
${ }^{29}$ SKB Menteri Agama No.1/1979 tentang Tatacara Pelaksanaan Penyiaran Agama dan Bantuan Luar Negeri kepada Lembaga Keagamaan di Indonesia, diakses 10 Agustus 2014, http://kemenag.go.id/file/dokumen/SKB11979.pdf.

${ }_{30}$ SKB Menteri Agama dan Menteri Dalam Negeri No.1/1969 yang mempersulit izin pembangunan gedung gereja diperkuat SKB No. 9 dan 8/2006 yang menyertakan peran FKUB, diakses 10 Agustus 2014, http://ntt.kemenag.go.id/file/file/dokumen/rndzl384483132.pdf.

${ }^{31}$ Salah satu telaah perda syariah dari perspektif perempuan, lihat Sri Wiyanti Eddyono, "Politisasi Islam dalam Transisi Demokrasi: Tantangan baru bagi gerakan perempuan di Indonesia", diakses 10 Agustus 2014, http://www.scncrest.org/id/images/dokumen/Politicizing\%20Islam\%20in\%20the\%20Transition\%2 0of\%20Democracyedisi\%20bahasa280710.pdf

${ }^{32}$ Lihat "Gerakan Islam Transnasional dan Pengaruhnya di Indonesia (direlease dan diedarkan oleh BIN)", diakses 10 Agustus 2014, http://www.unhas.ac.id/rhiza/arsip/orgtrans/Gerakan\%20Islam\%20Transnasional.pdf.
} 


\section{Gereja dan Politik}

Memasuki Indonesia merdeka gereja-gereja di Indonesia mempersiapkan diri menjadi "gereja Indonesia", yakni gereja-gereja yang bersatu menjalankan panggilan pelayanan dan kesaksian dalam Indonesia mengisi kemerdekaan Indonesia. Inilah esensi gerakan ekumene (oikoumene) gereja-gereja di Indonesia, yang digagas mengikuti perjuangan nasional menuju Indonesia merdeka, dan yang diwujudkan melalui pembentukan wadah-wadah keesaan gereja. Salah satunya adalah Majelis Kristen Indonesia bagian Timur, yang dibentuk di Malino pada 17 Maret 1947. Badan ekumene gereja-gereja di Indonesia bagian Timur ini menjadi pembuka jalan dalam proses pembentukan Dewan Gereja-gereja di Indonesia (DGI, sejak 1984 menjadi PGI) yang berhasil dibentuk pada Hari Pentakosta, tanggal 25 Mei 1950 di Jakarta. Demikianlah untuk Indonesia yang merdeka dan bersatu gereja-gereja berupaya menjadi satu, bukan untuk melebur menjadi satu organisasi gereja seperti Indische Kerk pada zaman kolonial, melainkan mewujudkan kesatuan dalam kepelbagaian, yakni banyak gereja namun dengan visi dan misi yang sama dalam beragam aksi kesaksian dan pelayanan masing-masing. Dengan demikian melalui gerakan ekumene gereja-gereja berusaha bersama mengisi kemerdekaan Indonesia melalui karya kesaksian dan pelayanan di tengah-tengah masyarakat Indonesia.

Gereja bukan sekadar lembaga ritual keagamaan, melainkan alat yang dihadirkan Tuhan di dalam dunia untuk kesaksian Injil Kerajaan Allah mengenai kasih, keadilan dan damai sejahtera Allah dalam Kristus. Karena itu gereja terpanggil untuk melakukan transformasi kehidupan manusia pribadi maupun masyarakat. Gereja berfungsi politik, bukan "politik kekuasaan" melainkan politik moral dalam membina Indonesia menjadi rumah kediaman bersama (oikos, home) masyarakat Indonesia yang majemuk.

Sampai awal Orde Baru ada Partai Kristen Indonesia (Parkindo), satu-satunya partai politik Kristen sejak 1945, yang mendaku diri sebagai partai nasionalis, yaitu yang memperjuangkan kepentingan seluruh bangsa, sesuai visi Kristen mengenai keadilan dan damai sejahtera bagi seluruh ciptaan. Di masa Orde Baru aktivis politik (beragama) Kristen banyak pula yang giat di dalam partai pemerintah yang berjaya masa itu, Golongan Karya (Golkar). Dan di masa Orde Baru pula banyak orang Kristen mendapat kepercayaan menduduki jabatan-jabatan penting di pemerintahan dan militer. Sampai sekarang ada kecenderungan memandang adanya pejabat-pejabat Kristen seperti itu sebagai hal baik, yang menguntungkan komunitas Kristen. Namun dalam perkembangan politik Indonesia, demokrasi 
yang bermutu tidak dapat dikembangkan secara primordial dengan bertolak dari basis agama, suku atau daerah yang mengotakngotakkan, masing-masing kelompok memperjuangkan diri sendirisendiri. Sebagai masyarakat majemuk, masa depan Indonesia yang demokratis harus dibangun dengan mengembangkan prinsip-prinsip kepemimpinan dan kewargaan yang bertanggung jawab, dengan visi kehidupan bersama yang memberi tempat pada kepelbagaiannya. Itulah makna semboyan nasional Bhinneka Tunggal Ika.

Sebab itu dalam surat pastoral Persekutuan Gereja-gereja di Indonesia (PGI) menyambut pemilu legislatif yang lalu, petunjuk pertama yang dicantumkan adalah "jangan memilih berdasarkan agama". Dalam penjelasannya, petunjuk ini menolak pendekatan agama yang sektarian, supaya kita tidak terkotak-kotak berdasarkan agama. ${ }^{33}$ Dalam pelayanan politik gereja, bukan terutama supaya orang-orang Kristen berkuasa, duduk di berbagai posisi penting untuk memuluskan kepentingan orang Kristen atau kepentingan gereja, melainkan supaya orang-orang yang baik, profesional dan berintegritas, dari berbagai latar belakang agama, Kristen atau bukan Kristen, bersama-sama melayani kepentingan seluruh masyarakat tanpa membeda-bedakan. Politik Kristen bukan politik kekuasaan dan kepentingan, melainkan politik pelayanan dan keadilan bagi seluruh warga masyarakat bangsa kita.

Karena dukungan masyarakat terhadap partai-partai politik Kristen makin kecil maka tidak ada lagi yang memenuhi election threshold. Partai politik Kristen hilang dari panggung politik nasional; namun ini tidak berarti tidak ada lagi atau tidak perlu lagi orang Kristen melayani di dunia politik. Politik Kristen yaitu yang memperjuangkan keadilan, perdamaian dan kesejahteraan serta kelestarian lingkungan tetap dapat dijalankan orang Kristen tanpa harus melalui suatu partai politik Kristen. Dan selain melalui partai politik, orang Kristen dapat melayani masyarakat dalam berbagai bidang profesinya. Untuk itu gereja wajib melakukan pendidikan

\footnotetext{
${ }^{33}$ Poin pertama sebagai berikut: Jangan Memilih Berdasarkan Agama! Salah satu persoalan pelik bangsa kita saat ini adalah menguatnya sektarianisme dan fanatisme atas dasar agama. Politisasi agama dalam Pemilu pun sangat kental dengan nuansa tersebut. Kita tidak ingin Pemilu menjadi ajang untuk semakin melestarikan atau memperkuat sektarianisme dan fanatisme ini. Pemilu harus kita maknai sebagai momentum untuk semakin memperkuat komitmen untuk memperkokoh NKRI. Karena itu, dalam memilih berilah penilaian berdasarkan kapasitas, kualitas dan rekam jejak figur, bukan berdasarkan agama. Memilih berdasarkan agama berarti kita memberi sumbangan terhadap keruntuhan NKRI di masa depan. "Pesan Pastoral MPH PGI kepada Segenap Umat Kristiani untuk Berpartisipasi dalam Pemilu Legislatif 2014”, diakses 10 Agustus 2014, http://pgi.or.id/archives/799.
} 
politik memperlengkapi warganya berperan dalam masyarakat. Selain pendidikan politik, peran politik gereja juga dijalankan sebagai kekuatan moral sosial melalui panggilan profetis menyampaikan kritik kenabian kepada pemerintah dan masyarakat menyangkut ketidakadilan dan kezaliman (pelanggaran HAM, perusakan lingkungan, diskriminasi). Ini terkait dengan posisi gereja/agama sebagai bagian penting dari penguatan civil society. ${ }^{34}$

Partisipasi politik Kristen di Indonesia selama ini tersandera dari dalam. Pertama, oleh Islamofobia, ketakutan terhadap Islam. Padahal tidak semua umat Islam menakutkan; di bidang politik terdapat kawan-kawan Islam sehaluan yang juga mempertahankan Pancasila, kebebasan dan kemajemukan, dan mau bersama-sama berjuang untuk keadilan dan kesejahteraan, serta menolak gerakan-gerakan radikalfundamental. Fenomena politik Islam memang merupakan masalah pelik dalam sejarah bangsa kita, baik yang gigih memperjuangkan ideologi Islam di jalur konstitusional, maupun yang terikut dalam garis keras gerakan transnasional yang mencita-citakan khalifah Islam sedunia. Di kalangan orang Kristen sering diungkapkan ketakutan terhadap politik Islam. Memang ada gerakan-gerakan politik Islam, namun sejak Pemilu pertama, tahun 1955, umat Islam Indonesia membuktikan diri sebagai mayoritas pendukung Pancasila. Sebab itu penting membina hubungan baik dengan semua saudara-saudara muslim/muslimah yang berpaham moderat, terbuka dan saling menghargai dalam perbedaan, untuk bersama-sama membina Indonesia sebagai rumah bersama.

Kedua, terkait dengan ketakutan itu, politik Kristen berfokus pada kepentingan sektarian dalam format primordialisme, dari Kristen oleh Kristen untuk Kristen. Politik Kristen seharusnya merupakan bagian dari pelaksanaan panggilan gereja melayani dunia dalam kerangka teologis kasih Allah - kepada dunia - melalui gereja.

Terkait pelayanan politik Kristen itu, juga perlu diberi perhatian di sini dua hal, yakni keterlibatan institusi/pimpinan gereja dalam politik, dan keterlibatan para pendeta secara pribadi. Pertama, gereja melayani di bidang politik, tetapi tidak boleh terlibat dalam "politik praktis" (politik kekuasaan), karena gereja bukan organisasi politik dan tidak boleh menjadi onderbouw (organisasi bawahan) suatu partai politik; pimpinan gereja tidak boleh menjadi tim sukses suatu partai atau kelompok politik dan mengambil hak pilih warganya untuk memilih partai politik atau calon yang seharusnya masing-masing pilih secara langsung, umum, bebas dan rahasia. Menyedihkan bahwa

\footnotetext{
${ }^{34}$ Selain Yesus, para nabi dalam Perjanjian Lama seperti Hosea, Amos, Yesaya, dan lain-lain menjadi teladan gereja dalam kritik sosial atas ketidakadilan.
} 
ada jemaat-jemaat di pedesaan dan di perkotaan yang "menjual" suaranya kepada caleg demi sejumlah uang atau materi untuk pembangunan gedung gereja. Itu termasuk money politics, dan secara teologis itu adalah dosa.

Dalam keadaan normal di mana pilihan-pilihan politik yang ada relatif baik, pimpinan/lembaga gereja harus bersifat netral. Hanya dalam keadaan genting di mana pilihan yang tersedia bersifat pilihan antara kebenaran dan kejahatan, maka gereja dapat memobilisasi warganya memilih kebenaran. ${ }^{35}$

Catatan kedua, menyangkut fenomena banyaknya pendeta menjadi (calon) legislator. Gereja-gereja berbeda pandangan dan perlakuan mengenai hal ini; ada yang mendukung ada pula yang menolak pendeta menjadi caleg, tentu dengan argumen masingmasing.

Penulis mencatat tiga alasan untuk menolak pendeta berpolitik praktis: menjadi caleg, menjadi tim sukses kampanye caleg/parpol, menjadi pengurus partai politik, atau menjadi pejabat negara. ${ }^{36}$ Alasan pertama, panggilan menjadi pendeta adalah panggilan khusus yang terkait dengan penyerahan diri secara utuh untuk menjadi pelayan gereja Tuhan; hidup dan pelayanannya seluruhnya terfokus pada gereja.

Alasan kedua, pendeta adalah pemimpin umat, yang harus mendampingi semua umatnya yang berbeda pilihan politiknya secara pastoral, bukan masuk pada salah satu pilihan politik dan menyisihkan yang lain. Seorang pendeta yang berpolitik sadar atau tidak akan memanfaatkan tugas pelayanan gereja untuk kepentingan

\footnotetext{
${ }^{35}$ Ketika menghadapi kekuatan politik Nazi di Jerman di bawah Adolf Hilter, sejumlah teolog dan pimpinan gereja menegaskan penolakan dengan merumuskan Deklarasi Barmen pada tahun 1934. Diakses 4 Agustus 2014, http://id.wikipedia.org/wiki/Deklarasi_Barmen. Dalam bahasa Inggris teks lengkap deklarasi rumusan Karl Barth ini berjudul "Theological Declaration of Barmen”, diakses 4 Agustus 2014, http://www.sacred-texts.com/chr/barmen.htm. Demikian juga Cardinal Jaime Sin (1928 - 2005) di Filipina melawan rezim Marcos dengan mengerahkan people movement. "He became witness to corruption, fraud and even murder at the hands of the regime - events that pushed Filipinos to the brink of civil unrest and even war. Sin appealed to Filipinos of all religions to follow the teachings of Jesus in the Gospels and use peaceful means to change the political situation in the Philippines," diakses 4 Agustus 2014, http://en.wikipedia.org/wiki/Jaime_Sin\#People_Power_movement

${ }^{36}$ Dalam sejarah Indonesia memang terdapat para pendeta yang bergiat di bidang politik, mengikuti pengaruh neo-Calvinisme teolog dan negarawan Belanda Abraham Kuyper (1837-1920), dan kemudian juga dalam sistem politik otoriter Orde Baru.
} 
politik partainya; mimbar pemberitaan firman Allah dapat menjadi mimbar kampanye, perkunjungan pastoral berubah fungsi menjadi konsolidasi partai, dan seterusnya.

Ketiga, kalau pun seorang pendeta mau berpolitik praktis, silakan memilih menjadi politikus; dia mempunyai hak konstitusional untuk itu sebagai warga negara. Tetapi dia harus meninggalkan sama sekali jabatan dan gelar kependetaannya, tidak boleh merangkapnya, supaya jangan mengabdi kepada dua tuan yaitu kepada pimpinan gereja dan pimpinan parpol. ${ }^{37}$

\section{Demokrasi Transaksional}

Tantangan politik pada masa Orde Baru adalah tiadanya kebebasan masyarakat menyuarakan aspirasi politik. Sedangkan di era Reformasi kini kebebasan politik disandera oleh kekuatankekuatan yang memainkan formalitas demokrasi dalam apa yang disebut demokrasi prosedural (kadang-kadang juga disebut demokrasi seolah-olah, as if democracy). Proses demokrasi berlangsung seolah-olah normal dengan adanya partai politik, pemilihan umum dan penetapan para wakil rakyat; pemilihan pejabat dari bupati sampai presiden. Semuanya mengikuti prosedur yang baku, namun sebenarnya telah dibajak substansinya oleh kekuatan-kekuatan yang tidak memihak keadilan dan kesejahteraan rakyat. Demokrasi prosedural tampak ketika kemudian para pejabat dalam lembagalembaga kekuasaan trias politica (pembagian kekuasaan legislatif, eksekutif dan yudikatif) ${ }^{38}$ menjalankan tugasnya demi kepentingan pribadi atau kelompok, bukan untuk kepentingan rakyat. Bahkan tidak sekadar prosedural, melainkan telah menjadi demokrasi transaksional. Hal ini diperlihatkan oleh kenyataan money politics, dari jual beli suara rakyat sampai uang sogok yang jumlahnya fantastik. Hasilnya, orang-orang yang mahir main suap dan pandai memperkaya diri yang terpilih. Dan bersama dengan itu muncul fenomena mega korupsi oleh perorangan dan berkelompok, yang melibatkan baik legislatif, maupun eksekutif dan yudikatif pada tingkat nasional sampai ke daerah-daerah provinsi dan kabupaten. ${ }^{39}$

\footnotetext{
${ }^{37}$ Dalam teologi Protestantisme mengenai jabatan gereja, jabatan bukan sakramen, tidak seumur hidup, melainkan terhubung dengan penugasan gereja. Kalau Tuhan memanggil melalui gereja orang menerima dan diteguhkan. Kalau atas alasan tertentu gereja mencabut penugasannya, maka jabatan itu berakhir. Begitu juga ketika seseorang meninggalkan jabatan kependetaan itu suatu panggilan lain.

${ }^{38}$ Mengenai "Trias politica", lihat "Separation of powers, diakses 10 Agustus 2014, http://en.wikipedia.org/wiki/Separation_of_powers

${ }^{39}$ Fenomena mega korupsi ini menjadi konteks pembentukan lembagalembaga antikorupsi, seperti Komisi Pemberantasan Korupsi (KPK, UU No.
} 
Reformasi politik nasional pasca mundurnya Presiden Suharto (1998) adalah liberalisasi politik dan desentralisasi (otonomi daerah). Ada optimisme bahwa liberalisasi dan desentralisasi akan membuka ruang partisipasi seluruh masyarakat, meningkatkan akuntabilitas dan transparansi, sehingga akhirnya tercapai tata pemerintahan yang lebih baik, yang bekerja keras bagi kesejahteraan rakyat. Tetapi, liberalisasi politik dan desentralisasi justru telah "dibajak" oleh kepentingan elite, yang menunjukkan fenomena khas dalam politik kita dewasa ini: raja-raja kecil di daerah, politik uang, politik identitas (agama, etnis, daerah), dan eksploitasi sumber daya alam (SDA). Penguasa (berkolusi dengan pengusaha) memakai segala macam cara untuk merebut dan mempertahankan kekuasaan (atau secara patrimonial, mewariskan kekuasaan kepada keluarganya layaknya dinasti raja-raja) ${ }^{40}$, sehingga dengan itu dapat menguasai dan mengeksploitasi sumber-sumber daya alam yang vital demi memperkaya diri atau kelompok sendiri. Penguasaan tanah dengan merebut tanah rakyat sering terjadi. ${ }^{41}$ Desentralisasi tidak menghasilkan demokratisasi, tata pemerintahan yang bersih (good governance) dan penguatan civil society di daerah, melainkan memunculkan fenomena desentralisasi korupsi, kolusi, dan kekerasan politik yang lebih seru daripada yang dulu terjadi di masa rezim terpusat Orde Baru.

Demikianlah demokrasi transaksional dan korupsi menjadi tantangan bagi pengembangan demokrasi substansial, yaitu demokrasi yang mengutamakan kesejahteraan dan keadilan sosial bagi seluruh rakyat. Mungkin meningkatnya angka golongan putih (golput, menolak memilih) pada beberapa pemilu terakhir merupakan respons kekecewaan masyarakat terhadap pemilihan wakil-wakil rakyat yang tidak membela atau memperjuangkan kepentingan rakyat. $^{42}$

30/2002) dan Pengadilan Tindak Pidana Korupsi (Tipikor, UU No 31/1999 direvisi menjadi UU No. 20/2011).

${ }^{40}$ Para pengemat juga memakai istilah oligarsi (oligarchy), yang menunjuk pada pemerintahan oleh sejumlah kecil orang yang menonjol karena kekayaan, pendidikan, hubungan keluarga, status sosial, atau agama. Di Indonesia oligarsi tampak dalam "dinasti penguasa", yang terikat hubungan keluarga dan bisnis, khususnya di sejumlah provinsi dan kabupaten. Lihat "Oligarchy", diakses 4 Agustus 2014, http://en.wikipedia.org/wiki/Oligarchy.

${ }^{41}$ Land grabbings merupakan salah satu isu panas di Indonesia dewasa ini, yang terutama berlangsung dalam persekongkolan penguasa dengan pengusaha tertentu.

${ }^{42}$ Pada Pemilu 2009, jumlah golput tercatat sebanyak 49.677.076 atau 29,1 persen, sedangkan tahun 2014 masih sebesar 24,89 persen (lebih 46 juta dari total pemilih 185.822.255). Lihat "data golput", diakses 4 Agustus 2014, http://id.wikipedia.org/wiki/Golongan_putih ; "Angka Golput menurun di Pemilu 


\section{Beberapa Agenda}

Jadi, konteks pelayanan politik dewasa ini adalah mengembangkan demokrasi substansial melawan demokrasi prosedural transaksional, khususnya dalam fenomena money politics dan korupsi serta oligarsi dan eksploitasi SDA. Demokrasi substansial diwujudkan dengan perhatian dan perjuangan para wakil rakyat dan pelaksana pemerintahan terhadap masalah-masalah masyarakat: menegakkan keadilan bagi semua kelompok yang diperlakukan tidak adil, mewujudkan perdamaian dan rasa aman dalam masyarakat, meningkatkan kesejahteraan rakyat, dan menjaga kelestarian alam/lingkungan hidup. Yang kita saksikan selama ini adalah ketidakadilan atau pembiaran terhadap kelompok-kelompok marginal. Kesulitan ekonomi memaksa laki-laki dan perempuan menjadi TKI/TKW, yang diperlakukan buruk di luar dan di dalam negeri. Di berbagai tempat tanah-tanah rakyat dirampas untuk kepentingan para pengusaha besar perkebunan atau pertambangan.

Dalam konteks itu sedikitnya perlu tiga agenda nasional. Pertama, membina kader politikus yang idealis, berwawasan nasionalis kerakyatan dan berjiwa Pancasila, menjunjung HAM, bersih dan berdisiplin; satu kata dan perbuatannya. Dan bersama dengan itu pendidikan politik, yakni membina warga masyarakat untuk turut mendukung pengembangan demokrasi yang sehat, menolak segala bentuk money politics dan menolak politik berbasis primordial agama, suku atau kedaerahan. ${ }^{43}$

Kedua, mengembangkan budaya kejujuran melawan "budaya" korupsi di semua bidang. Di Sulawesi Selatan kejujuran adalah nilai tertinggi dalam kebudayaan lokal. ${ }^{44}$ Membina kejujuran dimulai dari diri sendiri dan keluarga. Memang tidaklah mudah membangun budaya jujur di tengah menguatnya budaya pementingan diri, budaya

2014", diakses 4 Agustus 2014, http://politik.news.viva.co.id/news/read/503322angka-golput-menurun-di-pemilu-2014.

${ }^{43}$ Ini terutama tugas partai politik dan para pemegang kekuasaan (political society), yang perlu dukungan civil society (termasuk umat beragama) dan economic society (kalangan bisnis).

${ }^{44}$ Dalam kebudayaan di Sulawesi Selatan, kejujuran ditempatkan sebagai nilai yang utama: lempu' (Bugis), lambusu' (Makassar), lapu' (Mandar), malambu' (Toraja). Ini sebuah petuah dari budaya Makassar: "Ka antu jekkonga kammai batu nibuanga naung rilikua; na antu lambusuka kammai bulo ammawanga ri je'ne', nuassakkangi poko'na ammumbai appa'na, nuassakkangi appa'na ammumbai poko'na." (Kecurangan itu sama seperti batu yang dibuang ke dalam lubuk; tetapi kejujuran laksana bambu yang terapung di air, engkau tekan pangkalnya maka ujungnya timbul, engkau tekan ujungnya maka pangkalnya yang timbul). 
instant yaitu ingin serba gampang dan serba cepat, budaya koneksi, backing, budaya materialistik dan hidup mewah.

Tetapi ini suatu keharusan untuk mengubah secara mendasar cara berpikir dan bertindak demi masa depan baru bangsa kita. Hal ini yang dicanangkan oleh Joko Widodo, bakal Presiden Republik Indonesia mendatang sebagai "Revolusi Mental." ${ }^{45}$ Joko Widodo juga mengedepankan aspek lain dalam budaya kepemimpinan, yakni yang merakyat (egaliter), tampil sederhana dan berusaha memahami kebutuhan rakyat dengan mengunjungi dan berbicara langsung dengan kelompok-kelompok masyarakat pinggiran (blusukan). Hij is een van ons, kata orang. Ini berbeda dengan kepemimpinan feodal yang menjaga jarak dengan masyarakat dan mengutamakan kepentingan diri atau kelompoknya, bahkan tidak takut dan tidak malu hidup mewah dengan mencuri uang negara.

Aspek ekonomi merupakan pokok agenda ketiga. Kemajuan demokrasi berbanding lurus dan saling pengaruh dengan tingkat kesejahteraan masyarakat. Makin demokratis politik suatu bangsa maka makin sejahtera ekonominya, dan sebaliknya, makin baik ekonominya makin demokratis politiknya. ${ }^{46}$ Kita mendengar janji pemerintah akan memberi uang sekitar satu milyar setiap tahun kepada setiap desa. Apakah bantuan besar ini akan mewujudkan kesejahteraan masyarakat? Semoga demikian, dan bukannya memperluas budaya korupsi ke kalangan rakyat kecil. Hari-hari ini kita berhadapan dengan masalah BBM bersubsidi. Kita berharap pemerintah dan bangsa kita akan dapat mengatasi masalah ini juga.

Di mana tempat gereja dalam agenda-agenda perubahan nasional ini? Pertama, gereja sebagai lembaga perlu mengembangkan visi dan misi pelayanannya di bidang politik. Setiap gereja perlu mempunyai pedoman pelayanan di bidang politik, sebagai acuan pendidikan

45 "Apa yang mau dibidik oleh 'Revolusi Mental' adalah transformasi etos, yaitu perubahan mendasar dalam mentalitas, cara berpikir, cara merasa dan cara memercayai, yang semuanya menjelma dalam perilaku dan tindakan sehari-hari. Etos ini menyangkut semua bidang kehidupan mulai dari ekonomi, politik, sainsteknologi, seni, agama, dan sebagainya. Begitu rupa, sehingga mentalitas bangsa (yang terungkap dalam praktik/kebiasaan seharihari) lambat-laun berubah. Pengorganisasian, rumusan kebijakan dan pengambilan keputusan diarahkan untuk proses transformasi itu." Karlina Supelli, "Mengartikan Revolusi Mental", diakses 4 Agustus 2014, http://www.jokowi.id/opini/mengartikan-revolusi-mental/.

${ }^{46}$ Orde Baru memusatkan perhatian pada pembangunan ekonomi, yang kemudian ternyata gagal karena mengabaikan pembangunan budaya dan politik, serta pendekatan pembangunan ekonomi dari atas ekonomi negara dengan mengandalkan pinjaman, bukan memperkuat ekonomi masyarakat (ekonomi kerakyatan). 
politik dan pendampingan pastoral warganya. ${ }^{47}$ Politik tidak kotor, berpolitik bukan dosa. Sebagaimana telah disampaikan di atas, panggilan pelayanan gereja di bidang politik adalah pelayanan keadilan, perdamaian, kesejahteraan untuk semua, termasuk pelestarian alam/lingkungan hidup. Politik gereja adalah pelayanan, bukan kekuasaan; politik gereja adalah garam dan terang dunia, yakni memperjuangkan kebaikan bagi semua. Dalam hal itulah tanda-tanda kerajaan Allah dinyatakan dan nama Allah dimuliakan.

Kristus, Sang Pemegang segala kuasa di surga dan di bumi, berdaulat atas semua bidang kehidupan, termasuk bidang politik. Karena itu kemuliaan Allah juga harus dinyatakan di bidang politik, dengan mewujudkan kehendak-Nya, yakni keadilan, perdamaian dan kesejahteraan bagi semua. Itulah bagian dari panggilan gereja memberitakan Injil Kerajaan Allah, untuk menjadikan seluruh bidang kehidupan sebagai panggung kemuliaan Allah, theatrum gloria Dei. ${ }^{48}$

Kedua, gereja berkomitmen mendampingi secara pastoral warganya yang berkiprah di dunia politik, supaya mereka ikut dalam gerakan politik bersih, yang berkomitmen pada visi pelayanan politik, tegas menentang korupsi dan money politics. Bersama dengan itu, gereja melakukan pendidikan politik warganya untuk membangun sikap nasionalisme dan patriotisme, khususnya berwawasan Indonesia yang Pancasilais, menghargai perbedaan dan turut mengembangkan kejujuran dan tanggung jawab sesuai etika kristiani.

Ketiga, gereja memberi perhatian pada pelayanan sosial, baik pengembangan sumber daya manusia, maupun pengembangan sumber daya ekonomi. Pada masa lalu pekerjaan gereja melalui badanbadan zending/misi di Indonesia telah berjasa membuka daerahdaerah terpencil dan membangun kemajuan masyarakat pedalaman. Berbagai kemajuan dialami masyarakat-masyarakat yang dulu

\footnotetext{
${ }^{47}$ Sebagai contoh, lihat Zakaria J. Ngelow, "Pedoman Pelayanan Gereja di Bidang Politik" dalam John Campbell-Nelson dkk, eds, Teologi Politik: Panggilan Gereja di Bidang Politik Pasca Orde Baru (Makassar: Oase Intim, 2013), 291-299.

${ }^{48}$ Abraham Kuyper merumuskan: "There is not a square inch in the whole domain of our human existence over which Christ, who is Sovereign over all, does not cry, Mine!" Riwayat hidupnya baca "Abraham Kuyper", diakses 4 Agustus 2014, http://en.wikipedia.org/wiki/Abraham_Kuyper. "The whole world is a theatre for the display of the divine goodness, wisdom, justice, and power, but the Church is the orchestra, as it were - the most conspicuous part of it; and the nearer the approaches are that God makes to us, the more intimate and condescending the communication of his benefits, the more attentively are we called to consider them." John Calvin, "Commentary on Psalms - Volume 5", diakses 14 Agustus 2014, http://www.goodreads.com/quotes/tag/theatrum-gloriae-dei.
} 
terpencil menjadi masyarakat Indonesia yang maju karena pekerjaan gereja, seperti orang Batak, orang Toraja atau orang Papua. Dunia pendidikan memberi peluang bagi peran gereja untuk meningkatkan mutu sumber daya manusia Indonesia, yang dalam perbandingan dengan bangsa-bangsa lain masih sangat rendah, sebagaimana yang terungkap dalam fenomena TKI/TKW. ${ }^{49}$

\section{Kepustakaan}

“Abraham Kuyper”. Diakses 4 Agustus 2014. http://en.wikipedia.org/wiki/Abraham_Kuyper.

“Angka Golput menurun di Pemilu 2014". Diakses 4 Agustus 2014, http://politik.news.viva.co.id/news/read/503322-angka-golputmenurun-di-pemilu-2014.

“Anglicanism”. Diakses 4 Agustus 2014. http://en.wikipedia.org/wiki/Anglicanism.

Calvin, John, Commentary on Psalms - Volume 5. Diakses 4 Agustus 2014. http://www.goodreads.com/quotes/tag/theatrum-gloriaedei.

"Christian Catacombs", Diakses 4 Agustus 2014. http://www.biblearchaeology.info/catacombs.htm.

"Christian martyrs". Diakses 4 Agustus 2014. http://en.wikipedia.org/wiki/Christian_martyrs.

"Caesaropapism”. Diakses 4 Agustus 2014. http://en.wikipedia.org/wiki/Caesaropapism.

"Crucifixion". Diakses 4 Agustus 2014. http://en.wikipedia.org/wiki/Crucifixion.

"Cogito ergo sum", diakses 10 Agustus 2014, http://en.wikipedia.org/wiki/Cogito_ergo_sum.

"Cuis regio, eius religio". Diakses 10 Agustus 2014. http://en.wikipedia.org/wiki/Cuius_regio,_eius_religio.

"Data golput". Diakses 4 Agustus 2014. http://id.wikipedia.org/wiki/Golongan_putih,

"Deklarasi Barmen”. Diakses 4 Agustus 2014. http://id.wikipedia.org/wiki/Deklarasi_Barmen.

"Early Christian Catacombs". Diakses 4 Agustus 2014. http://www.sacred-destinations.com/italy/rome-catacombs

\footnotetext{
${ }^{49}$ Dalam Human Development Index 2013 Indonesia pada urutan ke-108 dari 187 negara dengan index HDI 0,684. Lihat "List of Countries by Human Development Index, diakses 4 Agustus 2014, http://en.wikipedia.org/wiki/_List_of_countries_by_Human_Development_Index.
} 
Eddyono, Sri Wiyanti. "Politisasi Islam dalam Transisi Demokrasi: Tantangan baru bagi gerakan perempuan di Indonesia". Diakses 10 Agustus 2014. http://www.scncrest.org/id/images/dokumen/Politicizing\%20Islam\%20in\%20the \%20Transition\%20of\%20Democracyedisi\%20bahasa280710.pdf

"English Reformation". Diakses 4 Agustus 2014. http://en.wikipedia.org/wiki/English_Reformation.

"Freedom of religion". Diakses 10 Agustus 2014. http://en.wikipedia.org/wiki/Freedom_of_religion.

"Gamaliel". Diakses 4 Agustus 2014. http://en.wikipedia.org/wiki/Gamaliel.

"Gelasius I". Diakses 10 Agustus 2014. http://www.newworldencyclopedia.org/entry/Gelasius_I.

"Gerakan Islam Transnasional dan Pengaruhnya di Indonesia (direlease dan diedarkan oleh BIN)". Diakses 10 Agustus 2014. http://www.unhas.ac.id/rhiza/arsip/orgtrans/Gerakan\%20Islam\%20Transnasional.pdf.

"HISTORY OF THE RENAISSANCE". Diakses 10 Agustus 2014. http://www.historyworld.net/wrldhis/plaintexthistories.asp?hist oryid=ac88.

"Humanism". Diakses 4 Agustus 2014. http://en.wikipedia.org/wiki/Humanism.

"Jaime Sin". Diakses 14 Agustus 2014. http://en.wikipedia.org/wiki/Jaime_SinłPeople_Power_movemen $t$

"List of countries by Human Development Index". Diakses 14 Agustus 2014. http://en.wikipedia.org/wiki/List_of_countries_by_Human_Devel opment_Index.

"Manifesto Perjuangan Partai Gerakan Indonesia Raya". Diakses 10 Agustus 2014. http://partaigerindra.or.id/uploads/ManifestoPerjuangan-Partai-Gerindra.pdf.

Nelson, John Campbell dkk, eds, Teologi Politik: Panggilan Gereja di Bidang Politik Pasca Orde Baru. Makassar: Oase Intim, 2013.

"Online Patristic Texts". Diakses 4 Agustus 2014. http://guides.lib.cua.edu/content.php?pid=160231\&sid=1635422.

"Oligarchy". Diakses 14 Agustus 2014. http://en.wikipedia.org/wiki/Oligarchy.

Olson, Carl. "Did St. Paul Invent Christianity?". Diakses 4 Agustus 2014. http://www.catholic.com/magazine/articles/did-st-paulinvent-christianity.

"Paul the Apostle" Diakses 4 Agustus 2014. http://en.wikipedia.org/wiki/Paul_the_Apostle. 
"Pencerahan”. Diakses 4 Agustus 2014. http://plato.stanford.edu/entries/enlightenment/

"Pesan Pastoral MPH PGI kepada Segenap Umat Kristiani untuk Berpartisipasi dalam Pemilu Legislatif 2014". Diakses 10 Agustus 2014. http://pgi.or.id/archives/799.

"Hillel the Elder". Diakses 4 Agustus 2014. http://en.wikipedia.org/wiki/Hillel_the_Elder.

"Sapere aude". Diakses 10 Agustus 2014. http://en.wikipedia.org/wiki/Sapere_aude.

"Sejarah Pembentukan Kementerian Agama”. Diakses 4 Agustus 2014. http://edokumen.kemenag.go.id/files/r5yH4vPql326688439.pdf.

"Separation of church and state" tersedia di http://en.wikipedia.org/wiki/Separation_of_church_and_state\#En lightenment.

"Separation of powers Diakses 10 Agustus 2014. http://en.wikipedia.org/wiki/Separation_of_powers.

"SKB Menteri Agama No.1/1979 tentang Tatacara Pelaksanaan Penyiaran Agama dan Bantuan Luar Negeri kepada Lembaga Keagamaan di Indonesia”. Diakses 10 Agustus 2014. http://kemenag.go.id/file/dokumen/SKBll979.pdf.

"SKB Menteri Agama dan Menteri Dalam Negeri No.1/1969 yang mempersulit izin pembangunan gedung gereja diperkuat SKB No. 9 dan 8/2006 yang menyertakan peran FKUB”. Diakses 10 Agustus 2014. http://ntt.kemenag.go.id/file/file/dokumen/rndz1384483132.pdf.

"State church of the Roman Empire". Diakses 4 Agustus 2014. http://en.wikipedia.org/wiki/State_church_of_the_Roman_Empire Supelli, Karlina. "Mengartikan Revolusi Mental". Diakses 4 Agustus 2014. http://www.jokowi.id/opini/mengartikan-revolusi-mental/

"Tertullianus". Diakses 10 Agustus 2014. http://en.wikipedia.org/wiki/Tertullian.

"The Missionary Journeys of the Apostle Paul". Diakses 14 Agustus, https://www.lds.org/scriptures/bc/images/03990_000_bible-map13.pdf.

"The Renaissance". Diakses 4 Agustus 2014. http://en.wikipedia.org/wiki/The_Renaissance.

"Thomas the Apostle". Diakses 4 Agustus 2014. http://en.wikipedia.org/wiki/Thomas_the_Apostle.

"Toleration". Diakses 10 Agustus 2014. http://en.wikipedia.org/wiki/Toleration.

"Two kingdoms doctrine". Diakses 10 Agustus 2014. http://en.wikipedia.org/wiki/Doctrine_of_the_two_kingdoms. 